\title{
PENGEMBANGAN SOAL PENALARAN MATEMATIS SISWA PADA MATERI PELUANG
}

\author{
Dea Meilisa Putri' ${ }^{1}$, Yuriska Destania ${ }^{2}$ \\ ${ }^{1}$ Program Studi Pendidikan Matematika, Universitas Muhammadiyah Bengkulu \\ 2Universitas Muhammadiyah Bengkulu, Indonesia \\ deameilisa97@gmail.com
}

\begin{abstract}
:
This research aimed to produce the product in the form of questions of valid and practical students' mathematical reasoning skills. The subjects of this study were 6 students of grade VIII to saw the readability of the given questions. The research and development method used the Tessmer model consisted of preliminary stage self-evaluation, expert review, one-to-one, small group, and field test. At the preliminary stage, there were two stages, namely preparation and design. The preparation of the stage was analyzing the curriculum, materials, and students' level. The design stage was done to design as questions of mathematical reasoning capabilities. The Self Evaluation stage was conducted after designed the questions of mathematical reasoning skills there were 15 questions and assesses whether the question meets the material, construction, and language. After evaluating the questions that would be validated by the expert reviewer and would be validated 3 times. After 14 questions validated that would be tested on 6 students to saw the practicality of the question through the student's responded questionnaire that was provided. Based on the result of the readability tested, the conclusion development of the questions from numbers 1 to 14 in the category of practicality were intervals of $4 \leq R P_{\text {produk }} \leq 5$ which were classified as Very Practical.
\end{abstract}

Keywords: Research and development, reasoning question, mathematical reasoning.

\section{PENDAHULUAN}

Matematika sebagai salah satu mata pelajaran yang memegang peran penting dalam pendidikan. Menurut Kemendikbud (2013) "Pembelajaran matematika dapat meningkatkan penalaran, berpikir logis, sistematis, kritis dan cermat serta terbuka dalam menghadapi permasalahan". Dalam kurikulum 2013 terdapat tujuan pembelajaran matematika yang dinyatakan oleh National Council of Teacher ofMatematics (Sumartini, 2015) yaitu koneksi (connection), penalaran (reasoning), komunikasi (communications), pemecahan masalah (problem solving) dan representasi (representations). Kemampuan ini juga terdapat dalam Permendikbud No. 36 Tahun 2018 pada kompetensi inti (KI 4) menyatakan Siswa mempunyai kemampuan mengelolah, menalar dan menyaji dalam ranah konkret dan ranah abstrak terkait dengan pengembangan dari yang diperlajarinya di sekolah secara mandiri, bertindak secara efektif dan kreatif, serta mampu menggunakan metoda sesuai kaidah keilmuan (Permendikbud, 2018).

Menurut Van den Walle (Rizta, Zulkardi, \& Hartono, 2013) "Standar kemampuan pembelajaran matematika dalam The National Council of Teachers of 
Mathematics (NCTM) menyebutkan "bahwa penalaran matematis dapat dilatih atau dikembangkan salah satunya dengan cara melatih penalaran dalam menyelesaikan soal" (NCTM, 2000). Pada prosespembelajaran siswa perlu dilatih dengan soal latihan yang mengarahkan pada kemampuan penalaran agar para siswa terbiasa dalam bernalar untuk menyelesaikan suatu permasalahan. Kemampuan penalaran matematis erat kaitannya dengan kemampuan siswa dalam menyajikan jawaban terurai secara bebas, sehingga soal essay cocok untuk melatih kemampuan penalaran matematis. Menurut Arikunto (2013) "Soal bentuk essay menuntut kemampuan siswa untuk mengorganisir, menginterprensi, menghubungkan pengetahuan yang telah dimiliki dan siswa harus memiliki kreativitas yang tinggi".

Menurut Rizta et al. (2013) "Ada beberapa faktor yang menyebabkan guru jarang melatihkan soal-soal yang membutuhkan penalaran". Salah satunya, yaitu ketersediaan referensi soal-soal penalaran yang dapat digunakan secara langsung dalam proses pembelajaran. Kemempuan penalaran siswa memiliki tingkatan yang berbeda-beda, untuk mengetahui kemampuan penalaran matematis siswa membutuhkan soal-soal yang sesuai dengan indikator-indikator penalaran matematis.

Hasil penelitian oleh Rizta et al. (2013) dalam penelitiannya tentang pengembangan soal penalaran model TIMSS matematika SMP menunjukkan bahwa Hasil uji coba diperoleh rata-rata hasl tes penalaran siswa adalah 4 siswa $(14,815 \%)$ tergolong mempunyai penalaran yang sangat baik, 4 siswa $(14,815 \%)$ tergolong penalaran yang baik, 8 siswa $(29,63 \%)$ tergolong mempunyai penalaran sedang, 6 siswa $(22,22 \%)$ tergolong mempunyai penalaran yang rendah dan 5 siswa (18,52\%) tergolong mempunyai penalaran yang sangat rendah.Hasil penelitian oleh Nursalam, Angriani, \& Usman (2017)dalam penelitiannya tentang pengembangan tes kemampuan penalaran matematis peserta didik madrasah tsanawiyah di Makassar menunjukkan bahwa hasil uji coba terbatas yang di lakukan diperoleh bahwa perangkat pembelajaran sudah dikatakan "valid" karena memiliki nilai CVI sebesar 1 dan reliabilitas tergolong reliabel dengan nilai sebesar 0,742 .

Sedangkan hasil penelitian oleh Wahyudi, Zulkardi, \& Darmawijoyo (2016) dalam penelitiannya tentang pengembangan soal tipe TIMSS menggunakan konteks budaya Lampung. Berdasarkan hasil penelitian, maka dapat disimpulkan bahwa soal penalaran tipe TIMSS menggunakan konteks budaya Lampung yang dikembangkan telah memenuhi kategori valid dan praktis. Kevalidan soal diperoleh dari proses validasi pada tahap expert review dan one to one, dimana pada tahap expert review para pakar menilai dari segi konten, konstruk, dan bahasa, sedangkan pada proses one to one untuk melihat keterbacaan soal oleh siswa. Adapun kepraktisan soal tergambar dari tahap small group dimana semua siswa dapat memahami maksud perangkat soal dengan baik, sesuai dengan alur pikiran siswa, mudah dibaca, tidak menimbulkan penafsiran yang beragam.

Berdasarkan hasil wawancara dengan salah satu guru matematika SMP Negeri 11 Kota Bengkulu, Terlihat saat proses pembelajaran dan diskusi berlangsung hanya sedikit siswa yang bisa menyelesaikan soal-soal yang membutuhkan kemampuan penalaran matematis. Selain itu, ketersediaan soal-soal yang dapat melatih kemampuan penalaran matematis masih sangat sedikit dan

Alifmatika: Jurnal Pendidikan dan Pembelajaran Matematika, Desember 2020, Vol. 2, No. 2 
belum memenuhi indikator-indikator kemampuan penalaran matematis. Adapun indikator kemampuan penalaran matematis, Menurut Sulistiawati \& Fatimah(2016) yaitu: (1) menyajikan pernyataan secara lisan, tertulis, gambar dan diagram; (2) mengajukan dugaan (conjectures); (3) melakukan manipulasi matematika; (4) menarik kesimpulan, menyusun bukti, memberikan alasan atau bukti terhadap beberapa solusi; (5) menarik kesimpulan dari pernyataan; (6) memeriksa kesahihan suatu argument; dan (7) menemukan pola atau sifat dari gejala matematis untuk generalisasi. Berikut contoh soal yang di dapatkan dari Buku Guru (As'ari, Tohir, Valentino, Imron, \& Taufiq, 2017) dan Buku paket siswa Matematika edisi revisi 2017 kelas VIII semester 2 (As'ari, Tohir, Valentino, Imron, Taufiq, et al., 2017) yang digunakan dalam proses pembelajaran disekolah.

1. Tentukan banyak titik sampel dari ruang sampel eksperimen:

a. 2 dadu

b. 1 koin 1 dadu

c. 2 koin 1 dadu

2. Sebuah dadu digelindingkan sekali. Berapa peluang kejadian:

a. mata dadu kelipatan tiga?

b. mata dadu bukan kelipatan tiga?

Gambar 1 Soal Latihan di Buku paket siswa

Pada Gambar 1 diatas dapat dilihat bahwa, Soal diatas merupakan soal latihan materi peluang. Soal-soal tersebut belum memenuhi indikator-indikator penalaran matematis. Soal diatas hanya menanyakan ruang sampel saja dan belum memenuhi indikator-indikator pelanaran matematis yang terdiri dari tujuh indikator, dari tujuh indikator tersebut dalam soal hanya empat indikator yang memenuhi indikator kemampuan penalaran matematis. Dimana seharusnya soal latihan untuk materi peluang harus ada hubungannya dengan penalaran dan kehidupan sehari-hari, agar siswa terbiasa saat diberikan soal-soal materi peluang yang berhubungan dengan kemampuan penalaran matematis. Untuk mengatasi permasalahan diatas, maka perlu dilakukan pengembangan soal-soal yang dapat melatih kemampuan penalaran matematis siswa di SMP.

Salah satu cara untuk mengembangkan soal penalaran matematis untuk memberikan siswa latihan berupa soal essay. Kelebihan soal essay menurut Arikunto (2018) "mendorong siswa untuk berani mengemukakan pendapat serta menyusun dalam bentuk kalimat yang bagus.Memberi kesempatan pada siswa untuk mengutarakan maksdunya dengan gaya siswa dan caranya sendiri.Dapat diketahui sejauh mana siswa mendalami sesuatu masalah yang diteskan". Menurut Tohir, Maswar, Atikurrahman, Saiful, \& Pradita (2020) mengatakan bahwa suatu masalah tertentu dikatakan masalah matematika apabila masalah tersebut mengandung konsep matematika yang dalam penyelesaiannya membutuhkan cara tidak langsung.

Oleh karena itu, untuk mengatasi permasalahan diatas, maka perlu dilakukan pengembangan soal-soal yang dapat melatih kemampuan penalaran matematis siswa di SMP. Menurut Gardner, et al. (Lestari \& Yudhanegara, 2015)

Alifmatika: Jurnal Pendidikan dan Pembelajaran Matematika, Desember 2020, Vol. 2, No. 2 
mengungkapkan bahwa penalaran matematis adalah kemampuan menganalisis, menggeneralisasi, mensisntesis atau mengintegrasikan, memberikan alasan yang tepat dan menyelesaikan masalah tidak rutin.Maka tujuan dalam penelitian ini adalah Menghasilkan butir soal yang valid dan praktis untuk kemampuan penalaran matematis siswa pada materi peluang yang dikembangkan.

\section{METODE PENELITIAN}

Jenis penelitian yang digunakan adalah penelitian pengembangan (development research). Dalam hal ini penelitian pengembangan bertujuan untuk menghasilkan produk berupa soal-soal untuk kemampuan penalaran matematis siswa. Metode Penelitian menggunakan model pengembangan dalam penelitian ini adalah model pengembangan formatve evaluation yang diacu dari Tessmer 1993 (Zulkardi, 2006). Adapun diagram alur dari penelitian pengembangan ini adalah sebagai berikut:

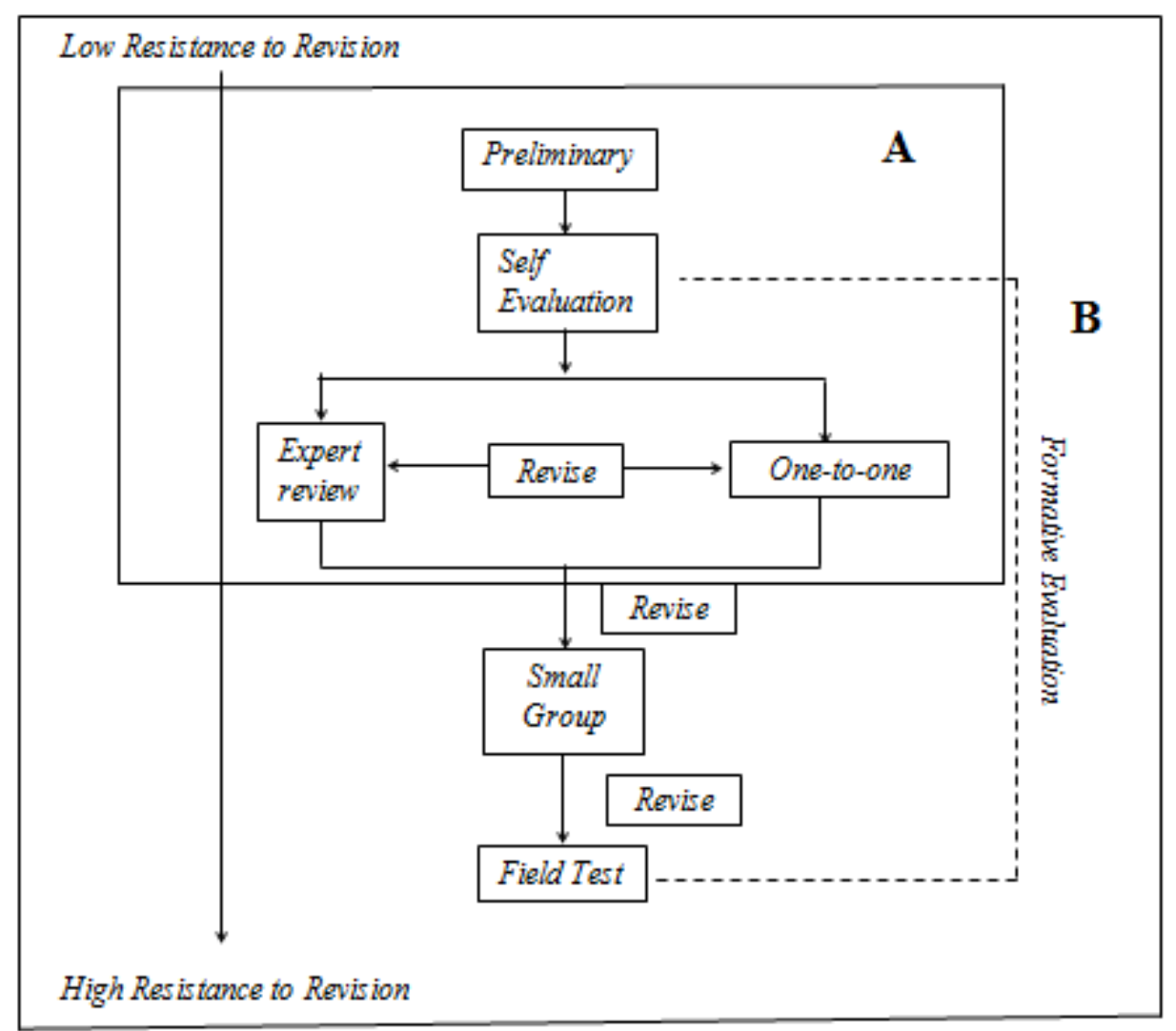

Gambar 2 Alur Desain Tessmer 1993 (Zulkardi, 2006)

Pada penelitian ini langkah Tessmer hanya sampai batas A yaitu, Tahap Preliminary, Self Evaluasion, Expert Review dan One-to-one, dan menghasilkan soal yang valid dan praktis. Alur Desain Tessmer 1993 (Zulkardi, 2006) melalui dua tahap pengembangan yang mana tahap tahap awal (preliminary) dan tahap formative evaluation. Pada tahap formative evaluation langkah-langkah yang 
dikemukakan meliputi (1) self evaluation (2) Prototyping (expert review, one-to-one dan small group) dan (3) field test.

Pada tahap preliminary, peneliti melakukan analisis kurikulum, analisis materi dan analisis siswa. Selanjutnya melakukan pendesainan kisi-kisi dan soal penalaran matematis. Setelah menghasilakan kisi-kisi dan soal-soal penalaran matematis dilanjutkan ke tahap formative evaluation.

Pada tahap formative evaluation, tahap pertama yang dilakukan yaitu self evaluation dimana peneliti melakukan penilaian sendiri terhadap desain yang telah dibuat.Hasilnya disebut dengan prototype I. Selanjutnya, prototyping yang terdiri dari expert review, one-to-one dan small group. Tahap expert review merupakan tahap validasi yang dilakukan oleh pakar (expert).Para pakar menelaah materi, konstruksi dan bahasa dari masing-masing prototype.Pada tahap ini tanggapan dan saran dari para validator digunakan untuk merevisi produk.Saran-saran dari pakar ditulis pada lembar validasi.

Secara bersamaan juga dilakukan tahap one-to-one. Pada tahap ini prototype I diujicobakan kepada 6 orang siswa untuk memberikan komentar dan mengisi angket terhadap soal. 6 orang siswa yang digunakan pada tahap one-to-one digunakan untuk uji keterbacaan soal terhadap siswa. Hasil dari komentar siswa digunakan untuk pertimbangan keterbacaan soal yang telah dibuat. Hasil yang diperoleh dari expert review dan one-to-oneakan menjadi pertimbangan untuk merevisi prototype I. Setelah prototype I direvisi akan menghasilkan protoype II. Prototype II akan diujicobakan pada tahap small group tidak dilakukan dikarenakan keterbatasan pada pandemi saat ini dan siswa yang digunakan pada tahap one-to-one adalah siswa kelas VIII SMP yang ada di lingkungan sekitar rumah peneliti.

Instrumen pengumpulan data yang digunakan dalam penelitian ini adalah dokumen, wawancara, lembar validasi, dan lembar angker respon siswa. Dokumen yang dimaksud adalah dokumen tentang kurikulum, materi, dan soal-soal kemampuan penalaran matematis. Wawancara dilakukan pada tahap one-to-one untuk siswa menanggapi keterbacaan dari soal yang diberikan. Lembar validasi berupa penilaian dari para pakar untuk soal yang sudah divalidasi yang mana lembar validasi berisi materi, konstruksi dan bahasa. Lembar validasi digunakan untuk penilaian dan informasi sebagai saran dan komentar dari para pakar tentang soal yang dihasilkan. Lembar angket respon siswa sebelumnya sudah di validasi oleh expert review yang mana didalam angket tersebut berisi alasan-alasan apakah soal-soal tersebut telah memenuhi kriteria. Lembar angket respon siswa digunakan untuk memperoleh data kepraktisan soal yang akan ditujukan kepada siswa. Hasil dari respon siswa akan dijadikan bahan untuk mengetahui keperaktisan soal. Instrumen ini digunakan pada tahap one-to-one untuk mrndapatkan data dari repon siswa.

Teknik analisis data yang digunakan pada penelitian ini adalah analisis kualitatif yaitu validitas dan praktis yang mana validitas harus memenuhi materi, konstruk dan bahasa.

1. Validitas

Teknik anaisis data validitas, prototype dilakukan pada tahap expert review. Pada tahap ini komentar dan saran validator di analisis secara kualitatif. Masukkan maupun saran dari validator dapat digunakan untuk merevisi prototype.Protype

Alifmatika: Jurnal Pendidikan dan Pembelajaran Matematika, Desember 2020, Vol. 2, No. 2 
direvisi berdasarkan dari berbagai coretan, komentar atau kalimat-kalimat yang belum tepat. Merevisi prototype dilakukan sehingga memperoleh soal yang valid dan layak di ujicobkan.

Kriteria pertimbangan validasi soal yaitu pada rekapitulasi lembar validasi hasil pertimbangan pada masing-masing validator. Validator memberikan nilai 1 (ya) apabila validator menganggap soal tersebut telah memenuhi materi, konstruk dan bahasa, nilai 0 (tidak) apabila validator belum mengaggap soal tersebut telah memenuhi materi, konstruk dan bahasa. Adapun kriteria penilaian validator yaitu dari segi materi, konstruk dan bahasa.

Setelah dilakukan validasi berdasarkan materi, konstruk dan bahasa. Validator memberikan kesimpulan apakah butir soal tersebut sudah valida atau tidak valid. Penilaian dari validator yang berbeda-beda tentang valid atau tidak valid terhadap soal yang berorientasi kemampauan penalaran matematis akan dianalisis menggunakan uji $Q$ Cochran Test. Adapun prosedur uji $Q$ Cochan adalah sebagai berikut:

a. Hipotesis yang diuji

Ho : Semua validator seragam menyatakan semua soal telah valid

Ha : Semua validator tidak seragam menyatakan semua soal telah valid

b. Mencari Q hitung dengan menggunakan rumus sebagai berikut:

$$
Q=\frac{(k-1)\left[k \sum_{j=1}^{k} G_{j}^{2}-\left(\sum_{j=1}^{k} G_{j}\right)^{2}\right]}{k \sum_{i=1}^{N} L_{i}-\sum_{i=1}^{N} L_{i}^{2}}
$$

(Sugiono, 2012)

Keterangan:

$Q \quad$ : Q hitung

$k \quad$ : jumlah validator

$G_{j} \quad$ : jumlah yang sukses (jumlah yang mendapat nilai 1)

$L_{i} \quad$ : jumlah yang sukses semua validator

$L_{i}^{2} \quad$ : kuadrat dalam $L_{i}$

Distribusi sampling Q mendekati distribusi Chi kudrat.Oleh karena itu untuk menguji signifikansi harga $\mathrm{Q}$ hitung, maka perlu dibandingkan dengan hargaharga kritis untuk Chi tabel.

c. Penentuan Q tabel

Dengan derajat kebebasan yang digunakan untuk Q tabel adalah $d k=k-1$, kemudian lihat di tabel nilai-nilai chi kuadrat.sehingga dakan di dapat taraf signifkansi dari tabel chi kuadrat.dalam penelitian ini taraf signifikansi berada pada $5 \%$.

d. Keputusan

Setelah melalui langkah-langkah diatas akan diambil suatu keputusan. Menurut Sugiono (2012) mengatakan bahwa: "Tolak Ho dan terima Ha, jika $Q$ hitung $\geq Q$ tabel" dan "Terima Ho dan tolak Ha, jika $Q$ hitung $<Q$ tabel".

e. Kesimpulan

1) Jika tolak Ho berarti proporsi butir soal valid oleh validator masih berbeda pada semua soal. Artinya belum ada kesepakatan diantara para validator 
tentang kevalidan butir soal. Bila hal ini terjadi, maka perlu dilakukan revisi terhadap butir soal yang belum valid.

2) Jika terima Ho berarti proporsi jawaban valid pada semua butir soal dianggap sama. Dengan demikian, semua validator dianggap sepakat mengenai kevalidan semua butir soal.

Pengujian $Q$ hitung dilakukan terus menerus sampai diperoleh nilai jika $Q$ hitung $<Q$ tabel.

2. Kepraktisan

Kepraktisan berarti memenuhi keterbacaan dari soal, untuk mengetahui nilai keperaktisan soal dapat dilihat dari respon siswa saat mereka diminta untuk membacanya.

Kepraktisan penggunaan produk dilihat dari tahap uji coba, dimana uji kepraktisan ini ditentukan dengan cara skor rata-rata kepraktisan siswa ke-I dibagi banyak siswa, skor rata-rata diambil dari hasil pengisian lembar kepraktisan penggunaan produk, nilai rata-rata hasil pengisian lembar kepraktisan produk tersebut dapat dicari dengan rumus sebagai berikut.

$$
\bar{M}_{p}=\frac{\sum_{i=1}^{n} \bar{P}_{i}}{n}
$$

Keterangan:

$\bar{M}_{p}$ : Rata-rata kepraktisan produk

$\bar{P}_{i} \quad$ : Skor rata-rata kepraktisan siswa ke-i

$n$ : Banyak siswa

Setelah dihitung rata-rata hasil penelitian lembar kepraktisan penggunaan produk, maka tingkat kepraktisan produk yang dihasilkan tersebut dapat ditentukan berdasarkan tingkat kategori pada tabel kriteria pengkategorian sebagai berikut:

Tabel 1 Kriteria pengkategorian kepraktisan

\begin{tabular}{cc}
\hline Interval Skor & Kategori Kepraktisan \\
\hline $4 \leq R P_{\text {produk }} \leq 5$ & Sangat Praktis \\
$3 \leq R P_{\text {produk }}<4$ & Praktis \\
$2 \leq R P_{\text {produk }}<3$ & Kurang Praktis \\
$1 \leq R P_{\text {produk }}<2$ & Tidak Praktis \\
\hline Diadaptasi dari Khabibah (Riwayati \& Ridzky, 2020)
\end{tabular}

Soal bisa dikatakan praktis jika interval skor rata-rata hasil pengisian lembar kepraktisan produk minimal berada pada interval kategori praktis yaitu $3 \leq R P_{\text {produk }}<4$ dan apabila produk berada ada interval $4 \leq R P_{\text {produk }} \leq 5$ maka produk dikategorikan sangat praktis. 


\section{HASIL DAN PEMBAHASAN}

Ada tiga tahap pada penelitian ini, yaitu preliminary, self evaluation, expert review dan one-to-one.Kegiatan yang dilakukan dalam penelitian pengembangan soal ini adalah sebagai berikut.

1. Preliminary

a. Persiapan

Pada tahap ini, dilakukan beberapa analisis yaitu sebagai berikut.

1) Analisis Kurikulum

Menurut Depdiknas (Mikrayanti, 2016) menyatakan bahwa materi matematika dan penalaran matematis dua hal yang sangat terkait dan tidak dapat dipisahkan, karena materi matematika dipahami melalui penalaran dan penalaran dipahami dan dilatihkan melalui belajar matematika, maka dalam menganalisis kurikulum indikator kemampuan penalaran matematis dengan materi Peluang harus memiliki kesamaan. Indikator dalam kemampuan penalaran matematis terdiri dari 7, yaitu : (1) menyajikan pernyataan secara lisan, tertulis, gambar dan diagram; (2) mengajukan dugaan (conjectures); (3) melakukan manipulasi matematika; (4) menarik kesimpulan, menyusun bukti, memberikan alasan atau bukti terhadap beberapa solusi; (5) menarik kesimpulan dari pernyataan; (6) memeriksa kesahihan suatu argument; dan (7) menemukan pola atau sifat dari gejala matematis untuk generalisasi.

Materi yang digunakan adalah materi yang paling banyak berhubungan dengan dunia nyata. Dimana materi Peluang yang diajarkan untuk melihat kemungkinan-kemungkinan yang terjadi dalam kehidupan sehari-hari.Materi Peluang juga memiliki keterkaitan dengan pokok bahasan lainnya seperti Himpunan.

2) Analisis Materi

Tujuan analisis materi adalah untuk mengidentifikasi bagian-bagian utama yang akan dipelajari pada materi pokok yaitu peluang. Dimana materi peluang memiliki alokasi waktu pembelajaran dan konsep-konsep yang harus dikuasi oleh siswa. Pada alokasi waktu pembelajaran, materi peluang memiliki waktu pembelajaran selama 10 jam pembelajaran yang terdapat dalam silabus. Materi peluang memiliki keterbatasan waktu untuk melatih soal-soal kemampuan penalaran matematis. Pada konsep, walaupun materi memiliki konsep yang hanya sedikit tetapi harus menggunakan penalaran yang sangat baik untuk mengerjakan soal-soal materi peluang. Dalam materi tersebut terdapat banyak konsep yang harus dikuasai siswa seperti himpunan, ruang sampel, titik sampel, peluang empirik dam peluang teroretik.

3) Analisis Siswa

Analisis siswa merupakan telaah tentang karakteristik siswa untuk disesuaikan dengan pengembangan soal. Karakteristik tersebut meliputi latar belakang pengalaman dan pengembangan kognitif siswa. Analisis Latar Belakang Pengalaman Siswa, sub pokok bahasan peluang yang dipelajari siswa kelas VIII, sebenarnya materi yang baru mereka kenalakan tetapi untuk materi ruang sampel dan titik sampel sudah di pelajari di materi himpunan. Sedangkan Analisis Perkembangan Kognitif Siswa, siswa kelas VIII SMP merupakan objek dalam penelitian ini rata-rata berusia 12-14 tahun. Pada rata-rata usia 12-14 tahun, individu sudah mampu menalar karena tahap ini masuk tahap operasional formal

Alifmatika: Jurnal Pendidikan dan Pembelajaran Matematika, Desember 2020, Vol. 2, No. 2 


\section{Dea Meilisa Putri \& Yuriska Destania}

yang merupakan tahap terakhir perkembangan menurut Piager. Karakteristik tahap ini adalah diperolehnya kemampuan untuk berpikir secara abstrak, menalar secara logis dan menarik kesimpulan dari informasi yang tersedia.

b. Pendesainan

Hasil analisis kurikulum, analisis materi, analisis siswa dijadikan acuan untuk mendesain soal kemampuan penalaran matematis.Langkah awal yang dilakukan pada tahap desain adalah menyusun kisi-kisi soal dengan melakukan analisis silabus.Analisis silabus bertujuan untuk mengetahui kompetensi inti (KI) dan kompetensi dasar (KD) dalam suatu materi.

2. Self Evaluation

Pada tahap ini, prototype yang telah didesain berdasarkan materi dan indikator yang berjumlah 15 soal dinilai dan diperbaiki sendiri secara materi, konstruksi, dan bahasa. Hal ini dilakukan sebelum proses expert review yang akan divalidasi oleh pakar.

\section{Expert Review}

Pada tahap expert review ini butir-butir soal yang telah didesain untuk kemampuan penalaran matematis ditelaah oleh tiga orang validator yang merupakan dua orang dosen Pendidikan Matematika Universitas Muhammadiyah Bengkulu dan satu orang guru SMP Negeri 11 Kota Bengkulu. Penelaah butir soal ini ditinjau dari materi, konstruksi dan bahasa. Telaah soal ini merupakan analisis secara kualitatif terhaap butir soal untuk validitas terutama content validity butir soal. Hasil telaah para pakar yang tertulis di lembar soal sebagai komentar dan saran validator. Berikut hasil validasi kisi-kisi dan salah satu soal hasil expert review.

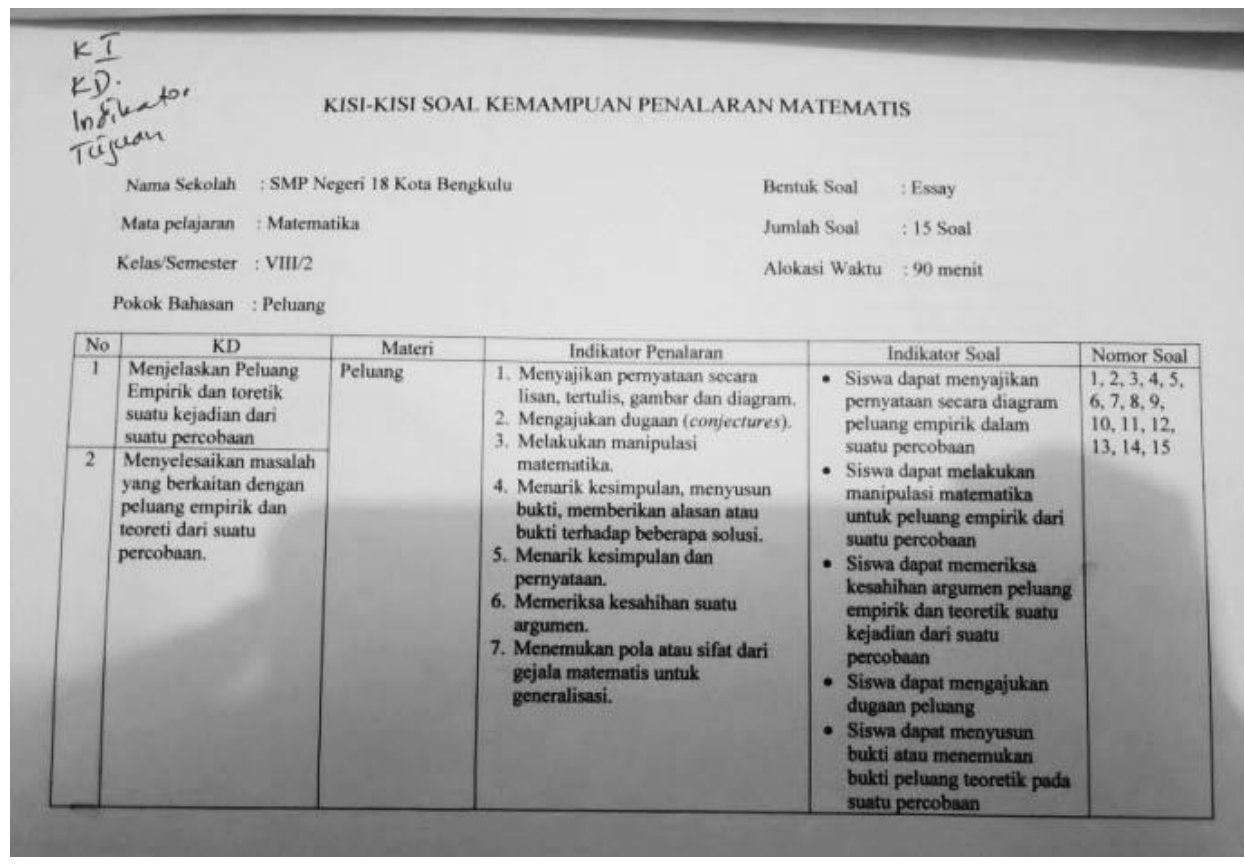

Gambar 3 Validasi Kisi-kisi

Pada validasi kisi-kisi ini validator menilai ketepatan dan kesesuaian antara indikator penalaran dan indikator materi apakah sudah sesuai dengan soal-soal

Alifmatika: Jurnal Pendidikan dan Pembelajaran Matematika, Desember 2020, Vol. 2, No. 2 
yang telah dibuat oleh penulis dan melihat tingkatan soal-soal tersebut sesuai atau tidak untuk kurikulum 2013 dan bagi anak SMP kelas VIII.

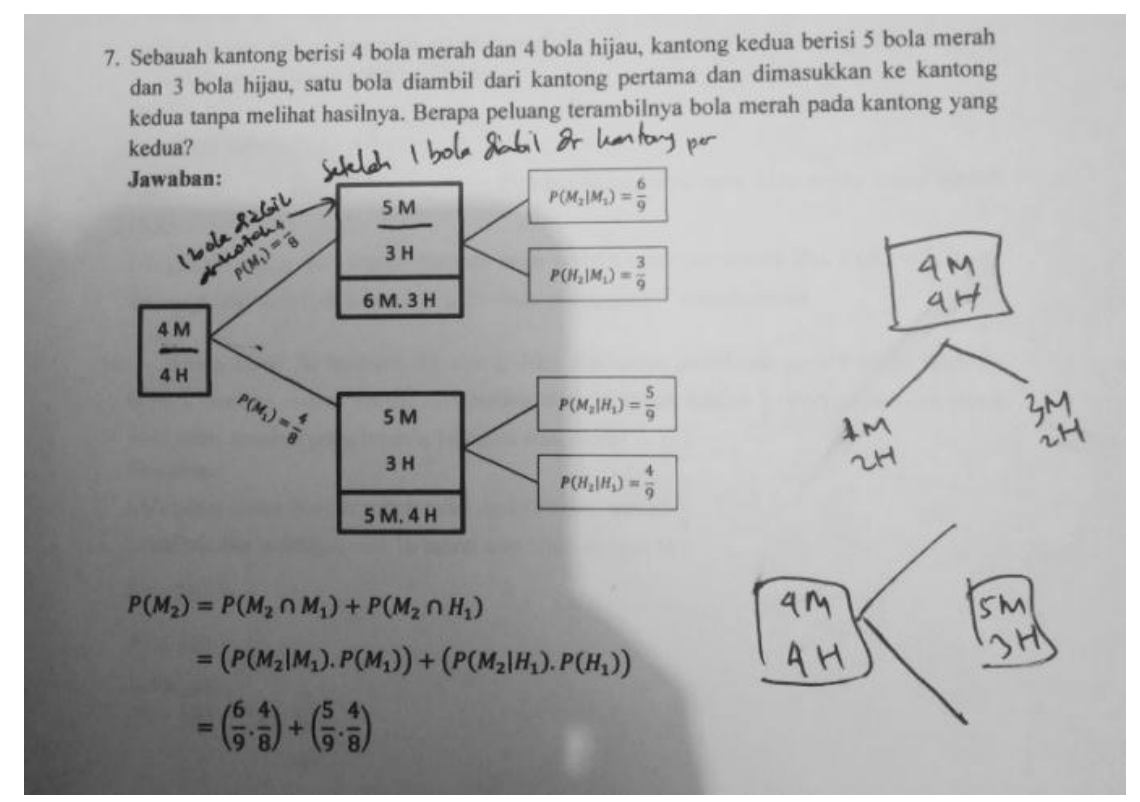

Gambar 4 Salah Satu hasi expert review

Pada validasi ketiga prototype sudah dinyatakan valid oleh kedua validator. Soal yang didesain divalidasi berdasarkan materi, konstruksi, dan bahasa. Selanjutnya penilaian dari validator dilakukan analisis menggunakan $Q$ Cochran untuk mencari keseragaman validator tentang kevalidan butir soal. Adapun hasil penilaian validator terhadap prototype I disajikan dalam tabel berikut.

Tabel 3 Penilaian Validator terhadap Butir Soal

\begin{tabular}{cccc}
\hline \multirow{2}{*}{ Nomor Soal } & \multicolumn{3}{c}{ Validator } \\
& V1 & V2 & V3 \\
\hline 1 & 1 & 1 & 1 \\
2 & 1 & 1 & 1 \\
3 & 1 & 1 & 1 \\
4 & 1 & 1 & 1 \\
5 & 1 & 1 & 1 \\
6 & 1 & 1 & 1 \\
7 & 1 & 1 & 1 \\
8 & 1 & 1 & 1 \\
9 & 1 & 1 & 1 \\
10 & 1 & 1 & 1 \\
11 & 1 & 1 & 1 \\
12 & 1 & 1 & 1 \\
13 & 1 & 1 & 1 \\
14 & 1 & 1 & 1 \\
\hline
\end{tabular}

Keterangan: $1=$ Valid, $0=$ Tidak valid

Alifmatika: Jurnal Pendidikan dan Pembelajaran Matematika, Desember 2020, Vol. 2, No. 2 
Berdasarkan Tabel 3 di atas terlihat bahwa validator 1, validator 2 validator 3 seragam, dikarenakan tidak ada satu butir soal yang berbeda.

\section{One-to-one}

Setelah soal selesai divalidasi oleh pakar dengan menghasilkan 14 soal yang valid, selanjutnya soal diujicobakan dengan 6 siswa untuk mendapatkan komentar pada setiap butir soal. Berdasarkan komentar siswa, sebagian besar siswa sudah memahami soal (terbaca). Kriteria Praktis Soal didapatkan dengan siswa membaca dan menilai soal tersebut pada angket yang telah diberikan. Berdasarkan angket respon siswa, didapatkan sejumlah data kepraktisan dalam penggunaan soal didapatkan rata-rata dari penilaian kepraktisan dari para siswa yang berdasarkan kriteria kategori kepraktisan, sebagai berikut:

Tabel 4 Kriteria Praktis Soal

\begin{tabular}{ccc}
\hline Nomor Soal & Nilai & Kategori Kepraktisan \\
\hline 1 & 4,167 & Sangat Praktis \\
2 & 3,958 & Praktis \\
3 & 4,208 & Sangat Praktis \\
4 & 3,958 & Praktis \\
5 & 4,208 & Sangat Praktis \\
6 & 3,938 & Sangat Praktis \\
7 & 4,063 & Sangat Praktis \\
8 & 4.063 & Sangat Praktis \\
9 & 4,292 & Sangat Praktis \\
10 & 4,083 & Sangat Praktis \\
11 & 4,271 & Sangat Praktis \\
12 & 3,979 & Praktis \\
13 & 4,146 & Sangat Praktis \\
14 & 4,083 & Sangat Praktis \\
\hline
\end{tabular}

Dari tabel 6 telihat hasil uji keterbacaan mendapatkan kesimpulan bahwa pengembangan soaldari nomor 1 hingga 14 dikategori kepraktisan berada pada interval $4 \leq \bar{x} \leq 5$ yang mana tergolong Sangat Praktis.

Penelitian ini menghasilkan soal untuk kemampuan penalaran matematis siswa yang valid dan praktis. Penelitian ini sejalan dengan penelitian Hazlita, Zulkardi, \& Darmawijoyo (2015) menunjukkan bahwa penelitian ini telah menghasilkan suatu produk pengembangan soal penalaran model TIMSS konteks Sumatera Selatan yang dapat digunakan untuk melatih kemampuan penalaran matematis siswa SMP. Berdasarkan hasil penelitian, maka dapat disimpulkan bahwa perangkat soal penalaran model TIMSS konteks Sumatera Selatan untuk mengetahui penalaran matematis siswa yang dikembangkan sebanyak 10 soal, yang terdiri dari 2 soal dari konten aljabar, 2 soal dari konten bilangan, 1 soal dari konten geometri dan pengukuran dan 5 soal dari konten data dan peluang. Kesepuluh soal penalaran matematis tersebut dapat dikategorikan valid dan praktis secara kualitatif maupun secara kuantitatif. Valid secara kualitatif tergambar dari hasil penilaian validator, dimana hampir semua validator 
menyatakan baik. Adapun valid secara kuantitatif tergambar berdasarkan analisis butir soal (validitas butir soal), sedangkan praktis tergambar dari ujicoba dimana semua siswa dapat menggunakan perangkat soal dengan baik. Dan juga Penelitian ini sejalan dengan penelitian dari Rizta et al. (2013) yaitu soal yang valid secara teoretik dapat dilihat dari hasil penilaian validator, yang semua validator menyatakan soal telah baik berdasarkankonten, kontruksdan bahasa dan praktis tergambar dari hasil uji coba one-to-one, dapat menggunakan perangkat soal dengan baik. Dan juga menghasilkan suatu produk pengembangan soal penalaran model TIMSS yang dapat digunakan untuk mengukur kemampuan penalaran matematis siswa SMP. Berdasarkan hasil penelitian berapa soal penalaran model TIMSS matematika SMP yang valid dan praktis. Hasil uji coba diperoleh rata-rata hasl tes penalaran siswa adalah 4 siswa $(14,815 \%)$ tergolong mempunyai penalaran yang sangat baik, 4 siswa $(14,815 \%)$ tergolong penalaran yang baik, 8 siswa $(29,63 \%)$ tergolong mempunyai penalaran sedang, 6 siswa $(22,22 \%)$ tergolong mempunyai penalaran yang rendah dan 5 siswa $(18,52 \%)$ tergolong mempunyai penalaran yang sangat rendah.

Penelitian ini hanya terbatas pada kriteria produk secara kualitatif yaitu valid dan praktis. Pengembang soal yang baik harus memiliki kriteria produk yang baik dalam pengembangan soal yang terstandar baik secara kualitatif maupun secara kuantitatif. Berikut ini adalah produk soal essay untuk kemampuan penalaran yang memenuhi kriteria secara kualitatif.

Tabel 5. Produk Soal Essay

\begin{tabular}{ll}
\hline No. & \multicolumn{1}{c}{ Soal } \\
\hline 1 & "Peluang dari suatu kejadian A adalah $\frac{n(A)}{n(S)}$, bernilai positif" \\
& Apa yang dapat anda jelaskan tentang kisaran nilai dari peluang kejadian A? \\
2 & $\begin{array}{l}\text { "Suatu kejadian A yang memiliki peluang nol, maka kejadian A mungkin terjadi”. } \\
\text { Benarkah pernyataan tersebut? Jelaskan. }\end{array}$
\end{tabular}

3 Dila dan Wika melakukan percobaan pelemparan dadu dan hasilnya seperti pada tabel di samping, mereka melakukan pelemparan sebanyak 140 kali, maka menurut Dila frekuensi kejadian munculnya mata dadu " 6 " adalah $\frac{11}{70}$, sedangkan menurut Wika frekuensi kejadian munculnya mata dadu "6" adalah $\frac{11}{36}$, Manakah dari pernyataan Dila dan Wika yang benar?

\begin{tabular}{|c|c|}
\hline Mata Dadu & Frekuensi (kali) \\
\hline 1 & 25 \\
\hline 2 & 22 \\
\hline 3 & 21 \\
\hline 4 & 24 \\
\hline 5 & 26 \\
\hline 6 & $?$ \\
\hline
\end{tabular}
Jelaskan. 


\begin{tabular}{ll}
\hline No. & \multicolumn{1}{c}{ Soal } \\
\hline 4 & Pada pelajaran matematika Anna, Chika, Irfan, Daniel, Wulan dan Cakra mendapat \\
& tugas kelompok dari gurunya untuk menemukan peluang empirik suatu \\
& percobaan. Mereka di berikan tugas untuk melakukan percobaan dengan \\
& melemparkan satu buah dadu sebanyak 140 kali. Mereka membagi tugas untuk \\
& mencatat kemunculan mata dadu hasil pelemparan mereka. Buatlah diagram yang \\
& menyajikan peluang empirik dari kejadian di atas.
\end{tabular}

\begin{tabular}{|c|c|c|}
\hline $\begin{array}{c}\text { Yang melakukan } \\
\text { percobaan }\end{array}$ & $\begin{array}{c}\text { Mata dadu } \\
\text { yang dimati }\end{array}$ & $\begin{array}{c}\text { Banyak } \\
\text { muncul mata } \\
\text { dadu }(A)\end{array}$ \\
\hline Anna & 1 & 23 \\
\hline Chika & 2 & 23 \\
\hline Irfan & 3 & 24 \\
\hline Daniel & 4 & 23 \\
\hline Wulan & 5 & 25 \\
\hline Cakra & 6 & 22 \\
\hline
\end{tabular}

5 Dalam rangka Hari Pahlawan, suatu sekolah menyelengarakan kegiatan senam sehat yang diikuti 480 peserta. Peserta terdiri dari 125 siswa kelas VII, 136 siswa kelas VIII, 139 siswa kelas IX, dan Bapak/Ibu guru dan karyawan. Jika dalam kegiatan tersebut disediakan sebuah dooprize, peluang Bapak/Ibu guru dan karyawan mendapatkan dooprize adalah $\frac{1}{4}$, benarkah? Jelaskan.

6 Mina kehilangan catatan nomor telpon seorang temannya, ia ingat bahwa nomornya terdiri dari 11 angka dan 8 angka awalnya adalah 08522177 ia akan menelpon dengan mencoba sembarang angka untuk 3 digit sisanya. Berapa peluang Mina akan menghubungi 3 digit sisanya saling berbeda dan bukan angka $0,3,6$ serta digit terakhirnya bukan angka 5 ?

7 Dari 30 siswa, 16 anak gemar Matematika, 13 anak gemar Fisika dan 5 tidak gemar keduanya, Jika dipilih seorang anak secara acak, Tentukan peluang terpilih anak yang gemar Matematika dan Fisika?

8 "Sebuah dadu berisi 6 dilempar sekali. Jika $P(A)=\frac{1}{3}$, maka kemungkinan kejadian A muncul mata dadu prima ganjil adalah benar" Benarkah penyataan tersebut? Jelaskan.

$9 \quad$ Jika percobaan melemparkan 3 buah koin satu kali. Tentukan ruang sampelnya? Jika peluang munculnya $\{A A G\}=\frac{3}{8}$, Benarkah pernyataan tersebut?

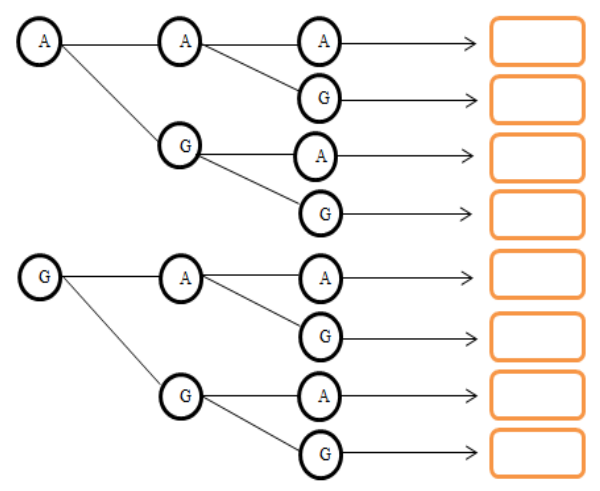


Pengembangan Soal Penalaran Matematis Siswa....

\begin{tabular}{ll}
\hline No. & \multicolumn{1}{c}{ Soal } \\
\hline 10 & Indra merayakan ulang tahun adiknya. Di akhir acara ulang tahun Indra akan \\
& memberikan bingkisan kepada anak-anak yang datang. Dalam bingkisan terdapat \\
& 4 jenis permen dan makanan lain,dari 4 jenis permen tersebut ada 15 permen \\
& kopiko,13 permen kiss, 16 permen lolipop dan 12 permen mentos. Jika diambil \\
& 1permen dari 4 jenis permen untuk dimasukkan ke dalam bingkisan. Peluang \\
& untuk terambilnya permen lolipop adalah $\frac{5}{7}$, permen kiss $\frac{43}{56}$, permen kopiko $\frac{41}{56}$ dan \\
& permen mentos $\frac{11}{16}$, benarkah pernyataan tersebut? Jelaskan.
\end{tabular}

11 Ibu Ina dan Ibu Cila melakukan percobaan dengan siswa kelas XI terdapat 36 siswa. Jika dilakukan pemilihan secara acak, peluang terpilih seorang siswa dengan usia kurang dari 16 tahun adalah $\frac{1}{4}$. Menurut Ibu Ina siswa yang berusia 16 tahun atau lebih ada 23 siswa dan menurut Ibu Cila sisa yang berusia 16 tahun atau lebih ada 27 siswa. Manakah dari pernyatan Ibu Ina dan Ibu Cila yang benar?

12 Ketika berjalan-jalan di sebuah acara televisi, Ilham mendapatkan kesempatan menjadi orang yang terpilih hari ini. Ilham berkesempatan memilih 1 hadiah dari 3 boneka yang disediakan oleh pihak acara. Setiap kotak berisi boneka kecil-kecil, boneka kelinci mewakili TV, boneka beruang mewakili Handphone, dan boneka panda mewakili Uang dengan komposisi sebagai berikut.

\begin{tabular}{|c|c|c|c|}
\hline Kotak & Boneka Kelinci & Boneka Beruang & Boneka Panda \\
\hline A & 6 & 7 & 8 \\
\hline B & 8 & 9 & 12 \\
\hline C & 10 & 12 & 17 \\
\hline
\end{tabular}

Ilham hanya diberikan kesempatan 1 kali untuk mengambil salah satu boneka tersebut. Menurut Ilham boneka kelinci yang memiliki peluang terbesar Ilham untuk mendapatkan TV? Buktikan.

13 Pada perayaan Hari Raya Idul Fitri, Dani memasukkan 40 permen berwarna ke dalam toples dan banyaknya permen yang dibagi seperti tampak pada diagram berikut:

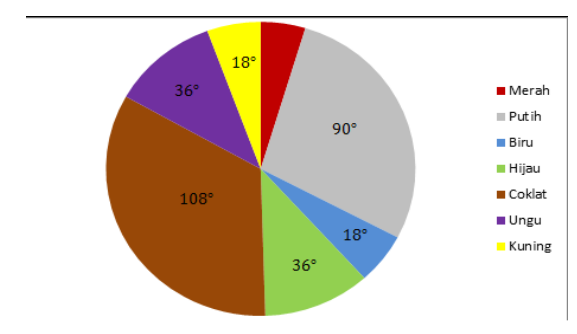

Dani mengambil satu butir permen dari toples tanpa melihat warnanya. Apakah eluang Dani mengambil permen berwarna merah $15 \%$, Buktikah?

14 Icha dan Dinda pergi ke perpustakaan yang sama dalam satu minggu selama 5 hari. Mereka masing-masing memiliki peluang yang sama untuk pergi ke perpustakaan pada 5 hari Selasa, Rabu, dan kamis. Maka berapa peluang mereka bisa pergi keperpustakaan pada hari yang sama adalah 0,32, Benarkah pernyataan tersebut? Berikan alasan. 


\section{KESIMPULAN DAN SARAN}

Penelitian ini menghasilkan produk soal essay untuk kemampuan penalaran matematis pada materi peluang. Berdasarkan hasil penelitian yang telah dilakukan dapat disimpulkan bahwa prototype soal yang dihasilkan sudah valid dan praktis (terbaca). Menghasilkan butir soal matematika untuk kemampuan penalaran matematis siswa yang valid sebanyak 14 soal. Valid tergambar dari hasil penilaian validator berdasarkan materi, konstruksi dan bahas. Menghasilkan butir soal matematika untuk kemampuan penalaran matematis siswa yang praktis (terbaca) sebanyak 14 soal. Praktis terlihat dari komentar siswadan sebagian besar siswa memahami soal sesuai dengan alur pikiran siswa. Kepraktisan (terbaca) pada soal dari nomor 1 hingga 14 berada pada interval $4 \leq R P_{\text {produk }} \leq 5$ yang mana tergolong Sangat Praktis.

Berdasarkan hasil penelitian yang dilakukan maka disarankan sebagai berikut: (1) Pengembangan soal penalaran matematis siswa diharapkan dapat membantu siswa untuk melatih diri dalam menyelesaikan soal penalaran matematis siswa dan juga untuk meningkatkan kemampuan penalaran matematis siswa. (2) diharapkan dapat melanjutkan penelitian pengembangan soal penalaran matematis siswa pada materi peluang ini ke tahap small group dan bias melanjutkan juga ketahap yang lebih luas yaitu tahap field test.

\section{DAFTARPUSTAKA}

Arikunto, S. (2013). Dasar-Dasar Evaluasi Pendidikan Edisi Revisi. Jakarta: PT Bumi Aksara.

Arikunto, S. (2018). Dasar-Dasar Evaluasi Pendidikan Evaluasi Pendidikan Edisi 3. Jakarta: Bumi Aksara.

As'ari, A. R., Tohir, M., Valentino, E., Imron, Z., \& Taufiq, I. (2017). Buku Guru Matematika (Revisi). Jakarta: Pusat Kurikulum Dan Perbukuan, Balitbang, Kemendikbud.

As'ari, A. R., Tohir, M., Valentino, E., Imron, Z., Taufiq, I., Hariarti, N. S., \& Lukmana, D. A. (2017). Matematika SMP/MTs kelas VIII semester 2. Edisi Revisi.

Hazlita, H., Zulkardi, Z., \& Darmawijoyo, D. (2015). Pengembangan Soal Penalaran Model TIMSS Konteks Sumatera Selatan di Kelas IX SMP. Kreano, Jurnal Matematika Kreatif-Inovatif, 5(2), 170-179.

Kemendikbud. (2013). Peraturan Menteri Pendidikan Nasional Pendidikan Republik Indonesia No 64 Tahun 2013 tentang standar isi untuk tingkat satuan pendidikan dasar dan menengah (pp. 1-111). pp. 1-111. Retrieved from https://luk.staff.ugm.ac.id/atur/bsnp/Permendikbud64-2013StandarIsi.pdf

Lestari, K. E., \& Yudhanegara, M. R. (2015). Penelitian pendidikan matematika. Bandung: PT Refika Aditama.

Mikrayanti, M. (2016). Meningkatkan kemampuan penalaran matematis melalui pembelajaran berbasis masalah. Suska Journal of Mathematics Education, 2(1), 97-102.

NCTM. (2000). Principles and Standards for School Mathematics. United States of America: The National Council of Teacher of Mathematics. 
Nursalam, N., Angriani, A. D., \& Usman, H. (2017). Pengembangan Tes Kemampuan Penalaran Matematis Peserta Didik Madrasah Tsanawiyah Di Makassar. Lentera Pendidikan: Jurnal Ilmu Tarbiyah Dan Keguruan, 20(1), 85-97.

Permendikbud. (2018). Peraturan Menteri Pendidikan dan Kebudayaan Republik Indonesia Nomor 36 Tahun 2018 tentang Perubahan atas Peraturan Menteri Pendidikan dan Kebudayaan nomor 59 Tahun 2014 tentang Kurikulum 2013 Sekolah Menengah atas/Madrasah Aliyah. Retrieved from Permendikbud website: 2018K13SMA-MALengkap.pdf

Riwayati, S., \& Ridzky, K. (2020). Pengembangan Bahan Ajar Materi Segitiga Melalui PMRI di Sekolah Menengah Pertama. Jurnal MATH-UMB. EDU, 7(2).

Rizta, A., Zulkardi, Z., \& Hartono, Y. (2013). Pengembangan Soal Penalaran Model TIMSS Matematika SMP. Jurnal Penelitian Dan Evaluasi Pendidikan, 17(2), 230-240.

Sugiono. (2012). Statistika Non parametrik Untuk Penelitian. Bandung: CV Alfabeta.

Sulistiawati, D. S., \& Fatimah, S. (2016). Peningkatan Kemampuan Penalaran Matematis Menggunakan Desain Didaktis Berdadasarkan Kesulitan Belajar pada Materi Luas dan Volume. Jppm.

Sumartini, T. S. (2015). Peningkatan kemampuan penalaran matematis siswa melalui pembelajaran berbasis masalah. Mosharafa: Jurnal Pendidikan Matematika, 4(1), 1-10.

Tohir, M., Maswar, M., Atikurrahman, M., Saiful, S., \& Pradita, D. A. R. (2020). Prospective teachers' expectations of students' mathematical thinking processes in solving problems. European Journal of Educational Research, 9(4), 1735-1748. https://doi.org/10.12973/eu-jer.9.4.1735

Wahyudi, T., Zulkardi, Z., \& Darmawijoyo, D. (2016). Pengembangan soal penalaran tipe TIMSS menggunakan konteks budaya Lampung. Jurnal Didaktik Matematika, 3(1), 1-14.

Zulkardi. (2006). Formative Evaluation: what, why, when and how. Retrieved from Oocities website: http://www.oocities.org/zulkardi/books.html 